\title{
CYTOTOXICITY AND DETECTION OF DAMAGE TO DNA BY 3-(5-NITRO- 2-THIENYL)-9-CHLORO-5-MORPHOLIN-4-YL[1,2,4]TRIAZOLO[4,3-C] QUINAZOLINE ON HUMAN CANCER CELL LINE HeLa
}

\author{
Renáta Ovádekováa*, Soňa Jantováb, Marica Theiszováb, Ján Labuda ${ }^{a}$
}

\author{
a Department of Analytical Chemistry, Faculty of Chemical and Food Technology, Slovak University of Technology, \\ Radlinského 9, 81237 Bratislava, Slovak Republic \\ ${ }^{b}$ Department of Biochemistry and Microbiology, Faculty of Chemical and Food Technology, Slovak University of Technology, \\ Radlinského 9, 81237 Bratislava, Slovak Republic \\ e-mail:renata.ovadekova@stuba.sk
}

Received: June 10, 2005; Accepted: September 25, 2005

Key words: Quinazoline derivative/HeLa cells/Cytotoxicity/DNA damage/DNA biosensor

Quinazolines - 1,3-benzodiazines are biological active compounds, which are used in the phamaceutical industry, in agriculture and in the medicine. As documented in the literature, many derivatives demonstrated anticancer activity and they act as multitarget agents. 3-(5-Nitro-2-thienyl)-9-chloro-5-morpholin-4-yl[1,2,4]triazolo[4,3-c] quinazoline (NTCHMTQ) - a new synthetically prepared quinazoline derivative was the most effective derivative in our primary cytotoxic screening. In this study, we evaluated cytotoxic/antiproliferative activity of NTCHMTQ using human tumor cell line HeLa. Possible interaction of 3-(5-nitro-2-thienyl)-9-chloro-5-morpholin-4-yl[1,2,4]triazolo[4,3-c] quinazoline with calf thymus DNA was tested by the DNA - modified screen - printed electrode. Quinazoline derivative acted cytotoxically on tumor cell line HeLa. The $\mathrm{IC}_{100}$ value was $10 \mu \mathrm{g} / \mathrm{ml}$. The $\mathrm{IC}_{50}$ values was found to be less than $4 \mu \mathrm{g} / \mathrm{ml}$, a limit put forward by the National Cancer Institute (NCI) for classiffication of he compound as a potential anticancer drug. Quinazoline at micromolar concentrations induced morphological changes and necrosis of HeLa cells. Using the DNA based electrochemical biosensor, we have not found damage to DNA under in vitro conditions at an incubation of the biosensor in mixture with quinazoline.

\section{INTRODUCTION}

Quinazoline derivatives are used in the pharmaceutical industry, in medicine and in agriculture because of their antimicrobial, anti-inflammatory, diuretic, anticonvulsant, antiallergic, antihypertensive, antiparkinsonian effects and other properties ${ }^{1-4}$.

As documented in the literature, many derivatives act as anticancer active compounds and they act as multitarget agents. They are antifolate thymidylate synthase inhibitors; epidermal growth factor receptor tyrosine kinase inhibitors; inhibitors of enzymes dihydrofolate reductase and tyrosine kinase, aldose reductase and cyclic GMP phosphodiesterase. Some quinazolines interact with cytoskeleton, they induce apoptosis and affect DNA topoisomerase $\mathrm{e}^{5-9}$.

3-(5-Nitro-2-thienyl)-9-chloro-5-morpholin-4-yl$[1,2,4]$ triazolo[4,3-c] quinazoline (NTCHMTQ) is new synthetically prepared derivative, which in our previous study showed cytotoxic effects on cancer cell line B16. Quinazoline at micromolar concentrations induced morphological changes and necrosis of B16 cells, at nanomolar concentrations it demonstrated changes of F-actin cytoskeleton. It did not cause changes in cell cycle, did not induce apoptotic cell death in B16 cells, did not have mutagenic effect.

The interactions of some anticancer agents with DNA have been investigated by a variety of techniques and there is a growing interest in the electrochemical methods for the determination of anticancer agents.

In this study, we investigated the cytotoxic effect of 3-(5-nitro-2-thienyl)-9-chloro-5-morpholin-4-yl$[1,2,4]$ triazolo[4,3-c] quinazoline on further cancer cell line HeLa and the electrochemical interaction of quinazoline with dsDNA at carbon paste electrode.

\section{MATERIAL AND METHODS}

We used the human tumor cell line HeLa obtained from the American Type Culture Collection (Rockville, MD, USA) which was adherently grown and propagated in supplemented minimal Eagle medium (Biocom Bratislava, Slovak Republic). Quinazoline prepared by Špirková et al. ${ }^{10,11}$ was dissolved in dimethyl sulfoxide (DMSO). All other chemicals were obtained from Sigma Chemicals (St Louis, MD).

Antiproliferative activity in vitro was measured by the cell growth inhibition assay. After $24 \mathrm{~h}$ of incubation, the 


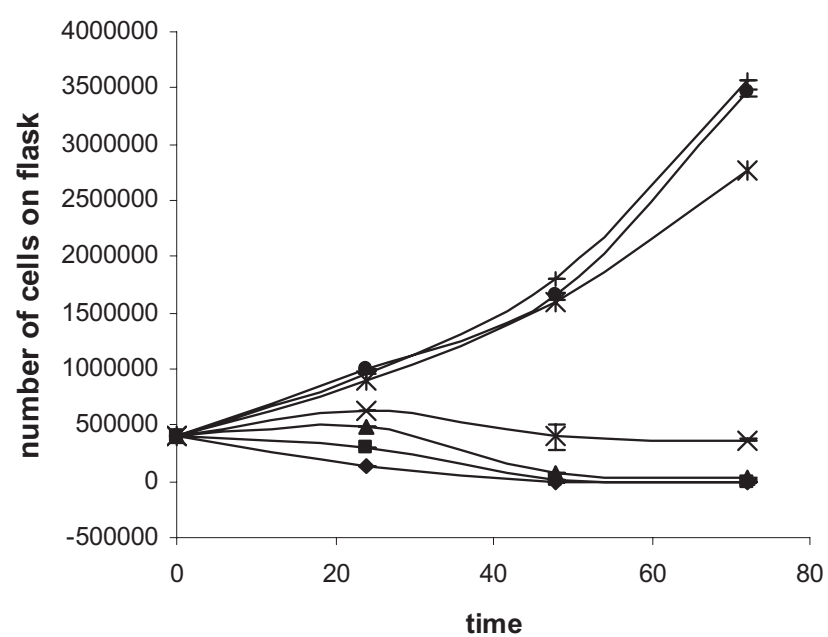

Fig. 1. The growth curves of HeLa cells treated for up to $72 \mathrm{~h}$ with NTCHMTQ.

Concentration of derivative $(\mu \mathrm{g} / \mathrm{ml}):+=$ control, $\downarrow=100$, $\boldsymbol{\square}=75, \boldsymbol{\Delta}=50, \times=10, *=1, \boldsymbol{\bullet}=0.1$. Data represent means \pm S.D. of three independent experiments. S. D. $<10 \%$.

(a)

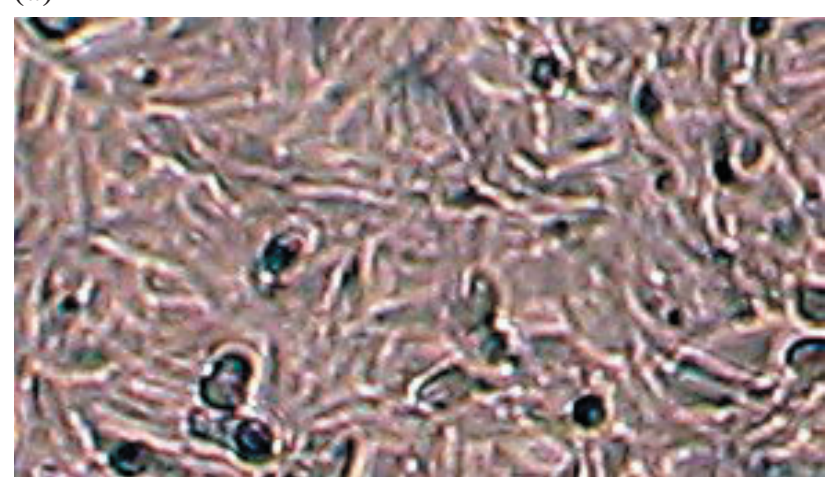

(c)

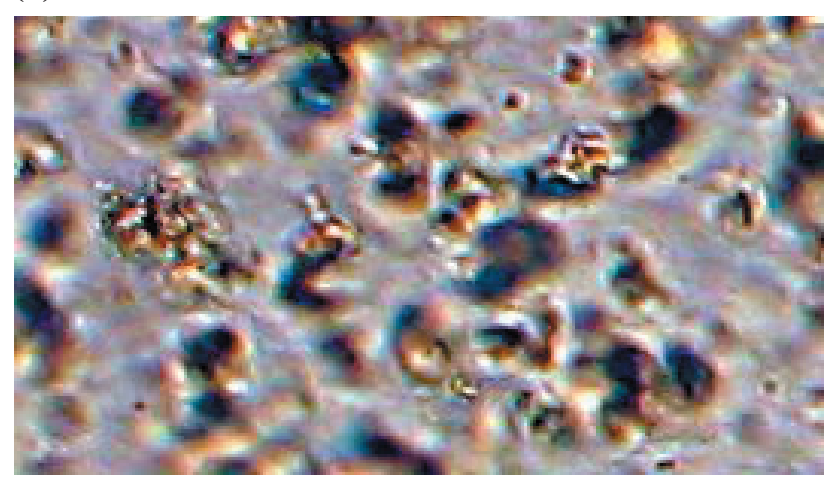

HeLa cells (the starting inoculum of $3 \times 10^{4}$ cells $/ \mathrm{ml}$ ) were treated with quinazoline (concentrations of 100 , $75,50,10,1,0.1 \mu \mathrm{g} / \mathrm{ml}$ ). Control cells were treated with DMSO, its final concentration never exceeded 1\%. After 24, 48 and $72 \mathrm{~h}$ of quinazoline treatment, HeLa cells were harvested in triplicate, first washed with PBS, then harvested by $0.25 \%$ trypsin, and latter resuspended. Cell growth and viability were assessed by direct counting of $0.4 \%$ trypan blue dye-excluding cells.

DNA-modified screen-printed carbon electrode was applied to the study of interaction between quinazoline and DNA at the electrode surface ${ }^{12}$. A computerized voltammetric analyzer ECA pol. fitted with a screen-printed three-electrode assembly including a carbon working electrode (SPE, $25 \mathrm{~mm}^{2}$ geometric surface area), a silver/silver chloride reference electrode $(\mathrm{Ag} / \mathrm{AgCl} / \mathrm{SPE}$ with potential of $0.284 \mathrm{~V}$ vs conventional $\mathrm{Ag} / \mathrm{AgCl} / \mathrm{sat}$. $\mathrm{KCl}$ electrode) and a carbon counter electrode was used for voltammetric measurements. The working electrode without any electrochemical preconditioning was chemically modified ex situ by covering with $5 \mu$ of the dsDNA stock solution and leaving the electrode to dry overnight.

Calf thymus dsDNA was obtained from Merck. Its stock solution $(0.1 \mathrm{mg} / \mathrm{ml})$ was prepared in $1 \times 10^{-2} \mathrm{~mol} / 1$

(b)

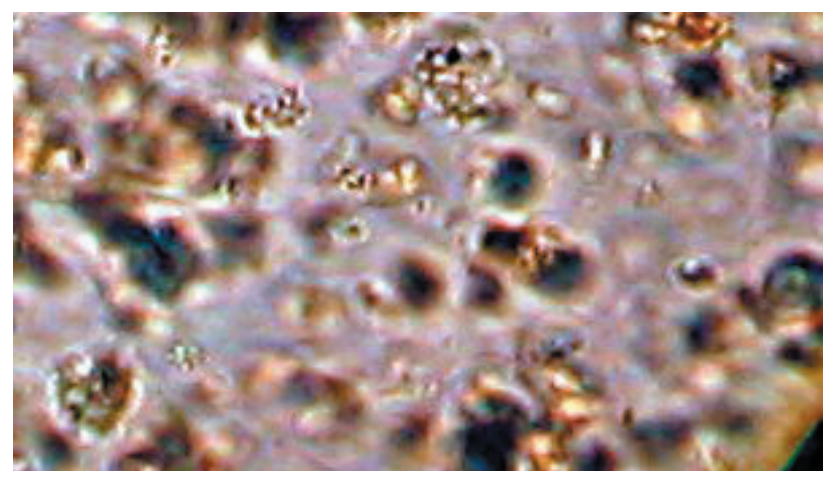

(d)

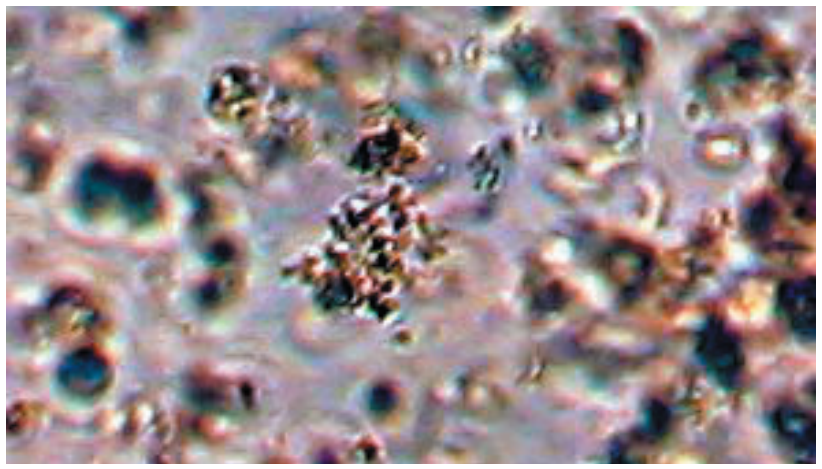

Fig. 2. The cytolytic effect of NTCHMTQ on morphology of HeLa cells during $72 \mathrm{~h}$ of influence. The control and treated cells grown on the cover slips. Then HeLa cells were taken out of the culture medium and photographed under a light microscope. Concentration of derivative $(\mu \mathrm{g} / \mathrm{ml})$ : $\mathrm{a}=$ control cells, $\mathrm{b}=100, \mathrm{c}=75, \mathrm{~d}=50$, magnification $10 \times 8$ 
(a)

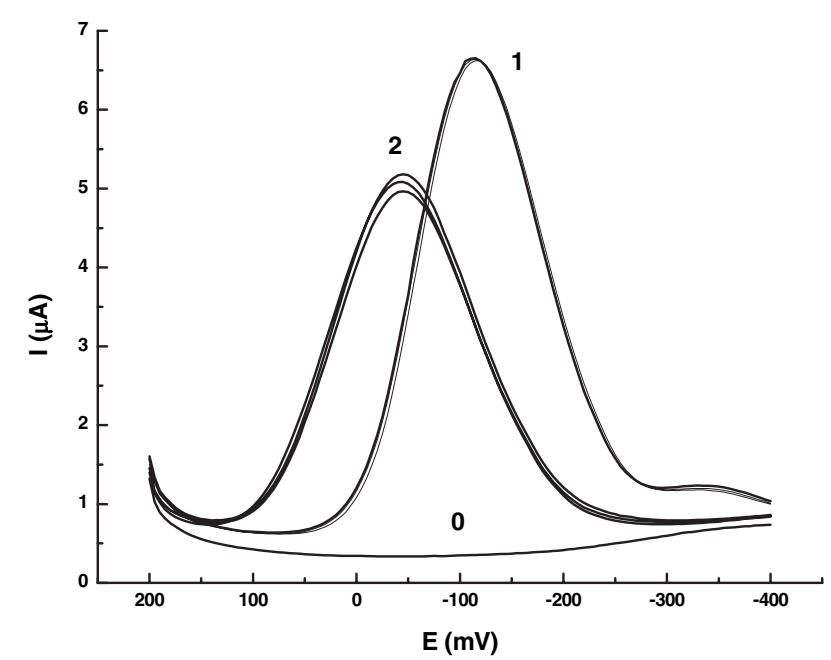

(c)

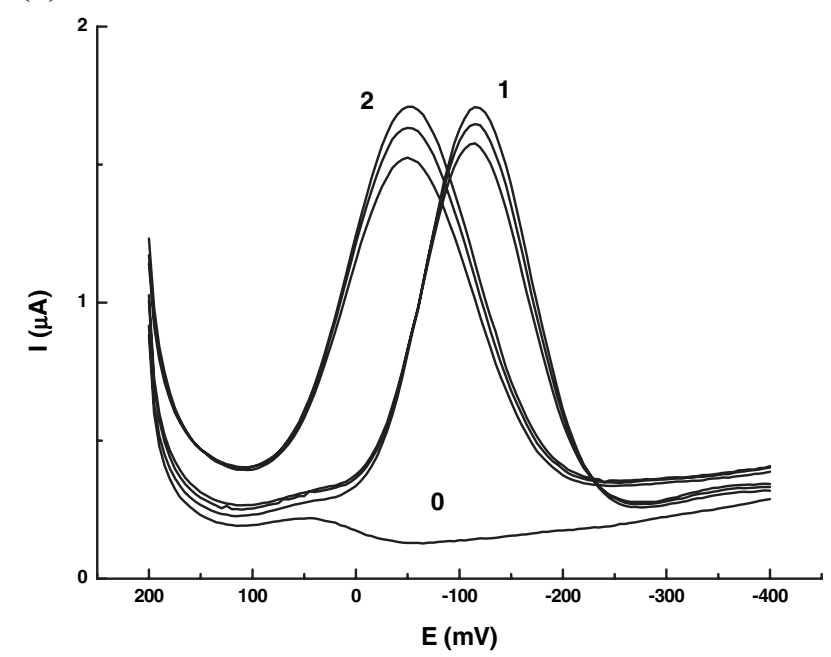

(e)

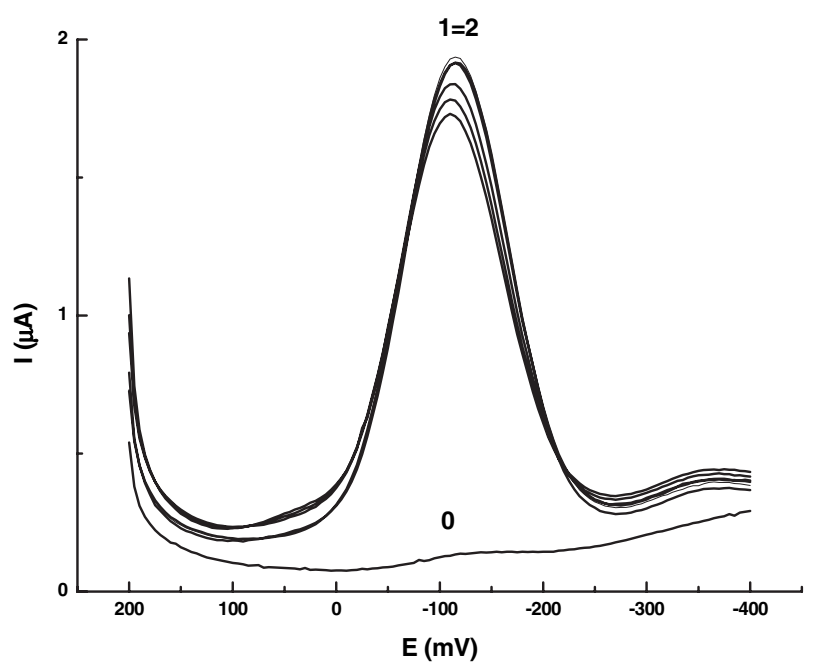

(b)

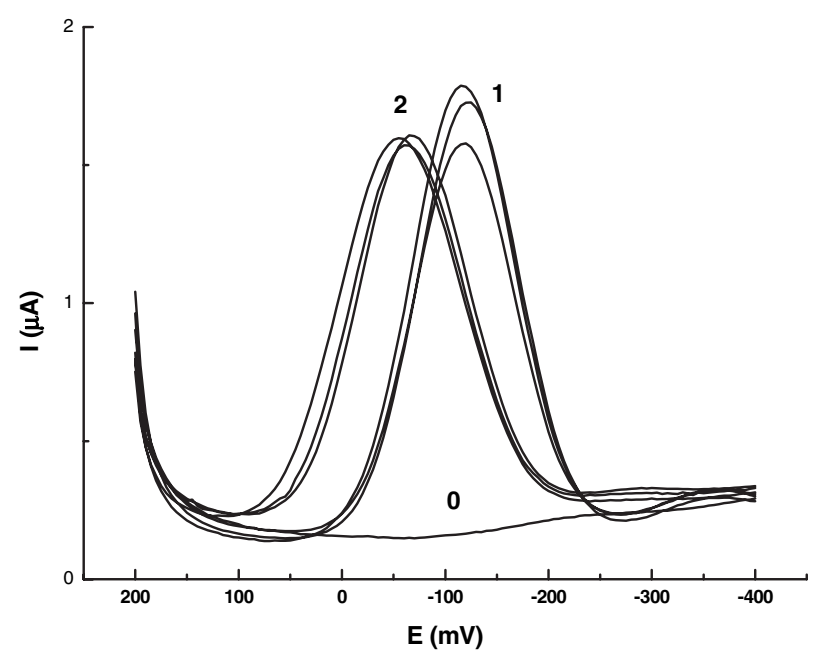

(d)

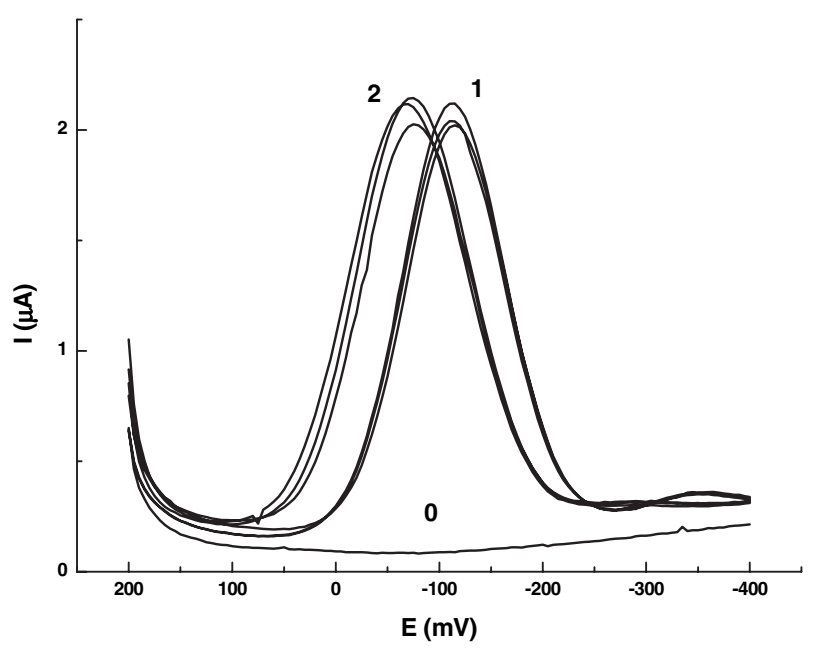

(f)

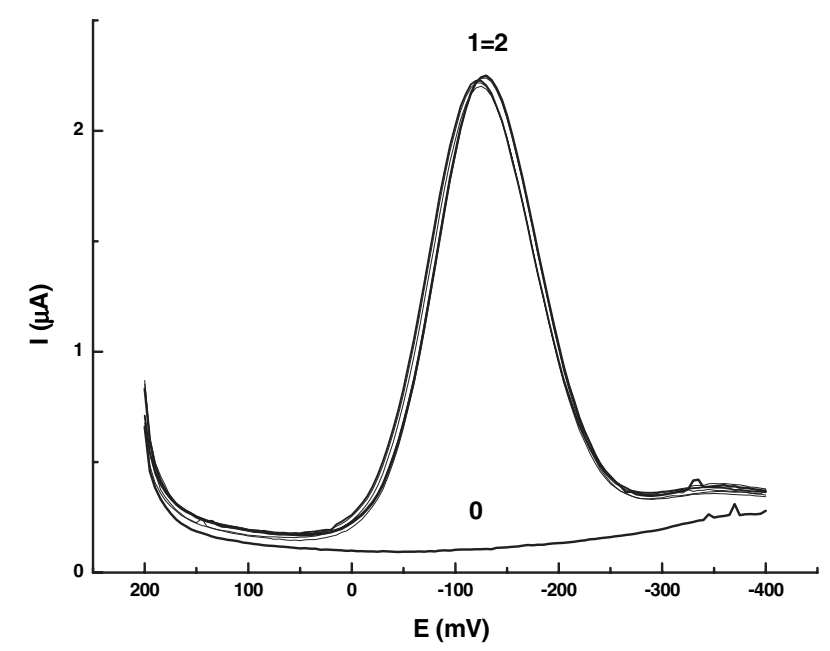

Fig. 3. DP voltammograms of the $\left[\mathrm{Co}(\text { phen })_{3}\right]^{3+}$ indicator at DNA/SPE before (1) and after (2) incubation in solution of 100 (b), 50 (c), 10 (d), 1 (e), 0.1 (f) $\mu \mathrm{g} / \mathrm{ml}$ quinazoline. (0) is blank. Control (a) is cis-Pt ( $5 \mu \mathrm{g} / \mathrm{ml})$. Conditions: $120 \mathrm{~s}$ accumulation from $5 \times 10^{-7} \mathrm{~mol} / 1\left[\mathrm{Co}(\mathrm{phen})_{3}\right]^{3+}$ in $5 \mathrm{mmol} / 1$ phosphate buffer solution of $\mathrm{pH} 7.0$. 
Table 1. Effect of quinazoline on DNA at 10 min incubation of DNA/SPE sensor in mixtures with quinazoline at $22{ }^{\circ} \mathrm{C}$. Conditions: $5 \mathrm{mmol} / 1$ phosphate buffer solution pH 7.0 under stirring. S.D. is $<10 \%$.

\begin{tabular}{|c|c|}
\hline $\begin{array}{c}\text { Concentration } \\
\text { of quinazoline }(\mathrm{mg} / \mathrm{l})\end{array}$ & $\begin{array}{c}\text { DNA } \\
\text { marker signal }\left(\mathrm{I} / \mathrm{I}_{0}\right)\end{array}$ \\
\hline 100 & $0.91 \pm 0.03$ \\
\hline 50 & $0.92 \pm 0.04$ \\
\hline 10 & $0.96 \pm 0.05$ \\
\hline 1 & $0.97 \pm 0.04$ \\
\hline 0.1 & $0.99 \pm 0.03$ \\
\hline No quinazoline & $0.99 \pm 0.05$ \\
\hline cis-Pt $(5 \mu \mathrm{g} / \mathrm{ml})$ & $0.72 \pm 0.02$ \\
\hline
\end{tabular}

Tris- $\mathrm{HCl}$ and $1 \times 10^{-3} \mathrm{~mol} / 1$ EDTA solution of $\mathrm{pH} 8.0$ and stored at $-4{ }^{\circ} \mathrm{C}$. As a dsDNA redox indicator the tris $(1,10$ phenanthroline)cobalt (III) $\left[\mathrm{Co}(\text { phen })_{3}\right]^{3+}$ complex was used. Concentrations of tested quinazoline were 100, 50, $10,1,0.1 \mu \mathrm{g} / \mathrm{ml}$.

The DNA/SPE sensor was pre-treated by immersing to $5 \mathrm{mmol} / 1$ phosphate buffer solution (PBS) pH 7.0 under stirring for $5 \mathrm{~min}$, and then rinsed with water. The $\left[\mathrm{Co}(\text { phen })_{3}\right]^{3+}$ marker was accumulated from $5 \mathrm{ml}$ of its $5 \times 10^{-7} \mathrm{~mol} / 1$ solution in $5 \mathrm{mmol} / 1 \mathrm{PBS}$ under stirring for $120 \mathrm{~s}$ at an open circuit. The differential pulse voltammogram (DPV) was recorded immediately from +0.300 to $-0.500 \mathrm{~V}$ at the pulse amplitude of $100 \mathrm{mV}, 2 \mathrm{mV}$ scan step and the scan rate of $10 \mathrm{mV} / \mathrm{s}$. The marker DPV peak current $\left(\mathrm{I}_{0}\right)$ was obtained using the evaluation against a base-line by standard software and the correction substancing the mean marker peak current measured at the unmodified SPE under the same condirions. Then, the DNA/SPE sensor was regenerated by a removal of the electrostatically accumulated $\left[\mathrm{Co}(\text { phen })_{3}\right]^{3+}$ ions from the DNA layer at treating in the buffer medium of higher ionic strength $\left(1 \times 10^{-1} \mathrm{~mol} / \mathrm{l} \mathrm{PBS} \mathrm{pH} 7.0\right)$ under stirring during $60 \mathrm{~s}$. To detect the damage to DNA, the same DNA sensor was incubated in a separate cell in the quinazoline mixture in $5 \mathrm{mmol} / \mathrm{l} \mathrm{PBS}$ for $10 \mathrm{~min}$ under stirring and then rinsed with water. The marker peak current (I) was obtained again in duplicate using the DPV measurement/biosensor regeneration scheme and the normalized (relative) signal $\mathrm{I} / \mathrm{I}_{0}$ was calculated.

\section{RESULTS AND DISCUSSION}

Figure 1 represents the growth curves of HeLa cells treated for up to $72 \mathrm{~h}$ with NTCHMTQ at concentrations ranging from $100 \mu \mathrm{g} / \mathrm{ml}$ to $0.1 \mu \mathrm{g} / \mathrm{ml}$. After $24 \mathrm{~h}$, the three highest concentrations tested $(100,75$ and $50 \mu \mathrm{g} / \mathrm{ml})$ had an acute cytolytic effect manifested by degeneration - lysis (necrosis) of certain parts of the HeLa cells. In the next time intervals the degeneration of cell population increased. The concentration of $10 \mathrm{mg} / 1$ induced a delayed cytotoxic effect. After $24 \mathrm{~h}$ of culturing $39.1 \%$ of the cell population proliferated but after $48 \mathrm{~h}$ and $72 \mathrm{~h}$ $100 \%$ degeneration of cell population was found. The concentration $1.0 \mathrm{mg} / 1$ of NTCHMTQ induced a cytotoxicity that was time-dependent. The HeLa cells treated for $72 \mathrm{~h}$ with the lowest concentration $(0.1 \mu \mathrm{g} / \mathrm{ml})$ grew as well as the control cells. These changes in viable cell number were also observed when aliquots of the cultures were examined by light microscopy.

The cytolytic effect of NTCHMTQ observed by light microscopy at concentrations $100,75,50 \mu \mathrm{g} / \mathrm{ml}$ for $\mathrm{HeLa}$ cells during $72 \mathrm{~h}$ of culturing is illustrated in Fig. 2. The control cells (Fig. 2a) grew on the surface of cultivation slide and during $72 \mathrm{~h}$ of incubating a monolayer was formed. Figures 2 b, c, d show significant morphology changes which occurred within $72 \mathrm{~h}$ in different stages of dying cell detachment from the covering slip. As seen from figures NTCHMTQ induces integrity damage of cytoplasmic membrane and lysis - necrosis of cells. The dying cells were stained by trypane blue dye.

The redox marker can be accumulated effectively within the DNA double helix from the $\left[\mathrm{Co}(\text { phen })_{3}\right]^{3+}$ solution at both a polarization of the modified electrode by a positive potential and an open circuit. Depending on an ionic strength of the medium, intercalation (predominantly at high ionic strength) and electrostatic forces (predominantly at low ionic strength) take part in binding of the marker particles. The interaction as well as electrostatic binding are equilibrium processes which can be utilized for a removal of $\left[\mathrm{Co}(\mathrm{phen})_{3}\right]^{3+}$ from the DNA layer in solution without $\left[\mathrm{Co}(\text { phen })_{3}\right]^{3+}$.

Damage to DNA was expressed by the relative signal I/ I, where I and I are the corrected marker DPV peak currents in experiments with and without NTCHMTQ (Table 1). Calf thymus DNA on biosensor was exposed to different concentrations $(100,50,10,1,0.1 \mu \mathrm{g} / \mathrm{ml})$ of NTCHMTQ. Typical DP voltammograms of the $\left[\mathrm{Co}(\text { phen })_{3}\right]^{3+}$ complex obtained at the DNA/SPE without and with quinazoline are shown in Fig. 3.

The treatment of the sensor in solution of quinazoline did not lead to a change in the signal. We can see (Fig. 3, Table 1) that NTCHMTQ did not cause change in calf thymus dsDNA. The little damage of dsDNA (only $9.3 \%$ ) was discovered only at concentration of $100 \mathrm{mg} / 1$. A potential shift of the guest molecule is usually taken as a confirmation of its binding mode.

Based on results obtained here we can conclude that 3-(5-nitro-2-tienyl)-9-chloro-5-morpholine-4-yl$[1,2,4]$ triazolo[4,3-c] quinazoline manifested the significant in vitro cytotoxic/antiproliferative effect on human cancer cell line HeLa. Using the DNA based electrochemical biosensor, we have not found damage to DNA under in vitro conditions at an incubation of the biosensor in 
mixture with quinazoline. Derivative at micromolar concentrations induced morphological changes and necrosis of HeLa cells.

\section{ACKNOWLEDGEMENT}

This study was supported by the Slovak State Committee for Scientific Research VEGA, grant number 1/1173/04 and project APVT 20-015904.

\section{REFERENCES}

1. Abdel-Rahman TM. (1998) Synthesis of some new biologically active 2,3-disubstituted quinazolin-4-ones. Boll Chim Farm 137 43-7.

2. Farghaly AM, Chaaban I, Khalil MA, Bekhit AA. (1990) Nonsteroidal antiinflammatory agents. Synthesis of novel 2-pyrazolyl4(3)-quinazolinones. Arch Pharmacol 323, 833-6.

3. Kornet MJ.(1992) Synthesis and anticonvulsant activity of 3alkyl-3,4-dihydro-2(1H)-quinazolinones. J Heterocyclic Chem 29, 103-5.

4. Jantová S, Urbančíková M, Maliar T, Mikulášová M, Rauko P, Čipák L, Kubíková J, Stankovský Š, Špirková K. (2001) Biological activity of some 4-anilinoquinazolines: cytotoxic, genotoxic and antiprotease effects, induction of necrosis and changes of actin cytoskeleton. Neoplasma 1, 52-60.

5. Tonkinson JL, Marder P, Andis SL, Shultz RM, Gossett LS, Shih Ch, Mendelsohn LG. (1997) Cell cycle effects of antifolate antimetabolites: implications for cytotoxicity and cytostatis. Cancer Chemother Pharmacol 39, 521-31.

6. Ranson M. (2004) Epidermal growth factor receptor tyrosine kinase inhibitors. Br J Cancer 90, 2250-5.

7. Takemura Y, Jackman A. (1997) Folate-based thymidylate synthase inhibitors in cancer chemotherapy. Anti-Cancer Drugs 8, 3-16.

8. Modjtahedi H, Affleck K, Stubberfield C, Dean C. (1998) EGFR blockade by tyrosine kinase inhibitor or monoclonal antibody inhibits growth, directs terminal differentiation and induces apoptosis in the human squamous cell carcinoma HN5. Int J Oncol 13, 335-42.

9. Holden SA, Teicher BA, Robinson MF, Northey D, Rosowsky A. (1995) Antifolates can potentiate topoisomerase II inhibitors in vitro and in vivo. Cancer Chemother 36, 165-71.

10. Špirková K, Stankovský S. (1991) Amidinoyl isothiocyanates in the synthesis of condensed quinazolines. Preparation of 3-aryl-5,9disubstituted-s-triazolo[4,3-c]quinazolines. Collect Czech Chem Commun 56, 1719-24.

11. Špirková K, Horňáček J, Stankovský Š. (1993) Amidinoyl isothiocyanates in the synthesis of condensed quinazolines. Preparation of 3-aryl-9-chloro5-morpholino[1,2,4] triazolo[4,3-c]quinazolines and their [1,5-c]isomers. Chem Papers 47, 382-5.

12. Labuda J, Bubničová K, Kovalová L, Vaničková M, Mattusch J, Wennrich R. (2005) Voltammetric detection of damage to DNA by arsenic compounds at a DNA biosensor. Sensore, in press 